\title{
Крупный бизнес в путинской России: старые и новые источники влияния на власть
}

\author{
И.А. MATBEEB*
}

\begin{abstract}
*Илья Александрович Матвеев - кандидат политических наук, доцент, факультет сравнительных политических исследований, Северо-Западный институт управления РАНХиГС. Адрес: 199178, Санкт-Петербург, Средний пр. В.О., д. 57/43. E-mail: matveev.ilya@yahoo.com
\end{abstract}

Цитирование: Матвеев И.А. (2019) Крупный бизнес в путинской России: старые и новые источники влияния на власть // Мир России. Т. 28. № 1. С. 54-74. DOI: $10.17323 / 1811-038 X-2019-28-1-54-74$

В научной литературе преобладает точка зрения, согласно которой российский крупньий бизнес в путинский период оказался полностью подчинен власти, что выражсается, в частности, в полном запрете на поддержку оппозиции и принудительном финансировании важных для государства проектов. Однако стремительный рост числа российских миллиардеров и их совокупного состояния в 2000-2010-е годы указывает на формирование в России политической и институциональной среды, благоприятной для крупного бизнеса. В настоящей статье утверждается, что картина политического влияния крупных собственников остается неполной без учета таких факторов, как структурная власть бизнеса (зависимость государства от экономических решений, принимаемых крупными компаниями), информационная асимметрия между государством и капиталом (преимущество крупных компаний в области информации и экспертизы), а также инструментальная власть бизнеса (формальные и неформальные канальв влияния). Если в 1990-е годы российский крупный бизнес обладал крайне высокой инструментальной, но низкой структурной властью, то в 2000-е и 2010-е годы на первый план выходит именно структурная зависимость государства от капитала: руководство странь проводит политику, выгодную крупным собственникам, с иелью поддержать уровень инвестиичий и экономического роста. В то же время у крупного бизнеса появляются новые каналь неформального влияния на власть, такие как сближение с бизнесменами из путинского ближнего круга. Согласно собранной в рамках исследования информации из открытых источников, 9 из 96 миллиардеров из российского рейтинга Forbes за 2017 год имеют или имели в прошлом широкие деловые связи с четырьмя близкими к В.В. Путину бизнесменами. Все эти факторы позволяют российскому крупному бизнесу играть активную, а не подчиненную роль в отночениях с государством. 
Ключевые слова: крупный бизнес, государство, лоббизм, неформальные связи, структурная зависимость, информационная асимметрия

\section{Введение}

Современная Россия - страна крупного бизнеса: число российских миллиардеров выросло с 17 в 2003 г., когда был впервые опубликован российский рейтинг Forbes, до 96 в 2017 г. (рисунок 1). Регрессионная модель, построенная Д. Трейсманом и учитывающая такие характеристики страны, как размер населения и подушевой ВВП, демонстрирует, что по мировым меркам число и совокупное состояние российских миллиардеров являются аномально высокими [Treisman 2016] ${ }^{1}$.

В то же время, согласно ряду оценок, высказанных в научной литературе, политическое влияние крупного бизнеса с приходом к власти В.В. Путина в 2000 г. (особенно после дела «Юкоса» 2003 г.) резко сократилось: так, по словам А. Яковлева, « $<. .>$ за короткий период времени отношения между бизнесом и государством перешли от модели “захвата государства” к модели неформального подчинения частного бизнеса государственным интересам: модели, которую можно обозначить как “захват бизнеса"» [Yakovlev 2006, p. 1048]. С точки зрения У. Томпсона, «российский частный капитал должен был стать не господином государства, а его слугой» [Tompson 2005]. Новый, подчиненный статус крупного бизнеса, как указывает ряд исследователей, выражается в «абсолютном политическом разоружении»: полном исключении какой-либо поддержки оппозиции [Паппэ, Галухина 2009, с. 7], а также в принудительном финансировании важных для государства проектов, таких как Олимпиада в Сочи [Müller 2011]. По словам политического аналитика Татьяны Становой, условием работы крупного бизнеса в путинской России является постоянная готовность «предоставлять государству и его акторам необходимые ресурсы вне зависимости от корпоративных рисков. То есть примат национальных интересов над частными» [Становая 2017]. Российский крупный бизнес в этой перспективе предстает куда менее политически влиятельным, чем его аналоги в других странах с мощным национальным капиталом, таких как США, и в других постсоветских государствах, имеющих историю «олигархии», таких как Грузия и Украина.

Тем не менее сам факт стремительного роста числа российских миллиардеров и их совокупного состояния указывает на благоприятную для крупного бизнеса политическую и институциональную среду, сложившуюся в путинской России. Кроме того, анализ индивидуальных корпоративных траекторий говорит о способности крупных собственников вести успешную лоббистскую деятельность, формула которой заключается не столько в подчинении государственным интересам, сколько в приватизации прибылей и обобществлении издержек [Гельман 2015]. Наконец, крупный бизнес демонстрирует способность к коллективной мобилизации: ему удается добиваться от государства уступок, задерживать принятие невыгодных для него законов или даже полностью блокировать их.

1 О высокой концентрации капитала в российской экономике также свидетельствует доля крупных компаний в ВВП (78\%) и занятости (73\%) (данные за 2014 г. см. [Струченевский 2016]). Для сравнения: в США доля крупного бизнеса в ВВП и занятости составляет около $50 \%$. 


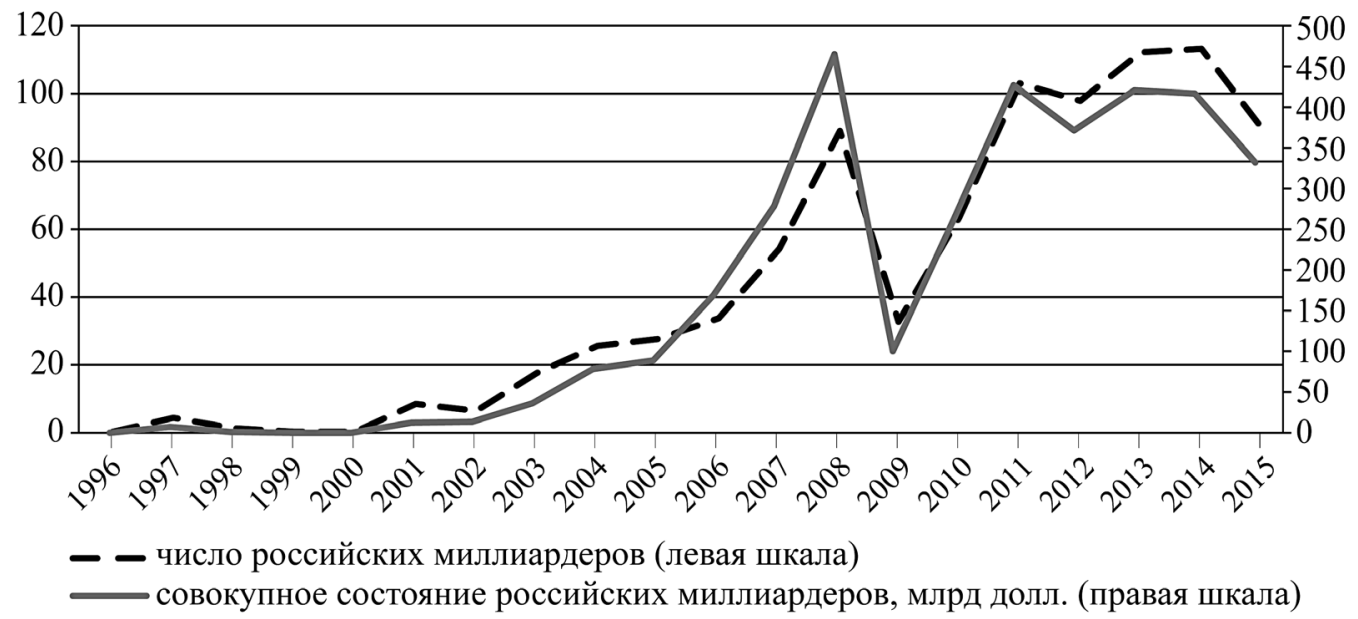

Рисунок 1. Число и совокупное состояние российских миллиардеров Источник: [Treisman 2016] на основе данных Forbes.

Тезис настоящей статьи заключается в том, что подчинение крупного бизнеса государству в путинский период - элемент скорее риторики (как представителей государства, так и самих крупных собственников), чем реального положения дел. На стороне государства - централизация процесса принятия решений, замкнутого на Кремль, нелегитимность в глазах населения крупного бизнеса, особенно берущего начало в приватизационных сделках, а также мощный госсектор, доминирующий в ряде стратегических отраслей. В то же время на стороне крупных собственников - сохраняющаяся высокая структурная зависимость государства от экономических решений, принимаемых частными компаниями, информационная асимметрия между государством и капиталом, а также высокий уровень инструментальной власти, включающей как формальные, так и неформальные каналы влияния. Все эти преимущества позволяют крупному бизнесу играть активную, а не подчиненную роль в отношениях с государством, и не столько воплощать в жизнь государственные задачи, сколько использовать государство в своих интересах.

\section{Крупный бизнес и государство: подчинение или активная роль?}

Исследования показывают, что российский крупный бизнес, в отличие от среднего и малого, чаще прибегает к индивидуальному лоббизму, чем к коллективному в составе отраслевых ассоциаций [Duvanova 2011]. В качестве примера успешной индивидуальной лоббистской стратегии можно привести деловую активность О. Дерипаски. Произнесенная им в 2007 г. фраза «Если государство скажет, что мы должны отказаться [от компании "Русал" - примечание автора], мы откажемся. Я не отделяю себя от государства. У меня нет других интересов» [Белтон 2007] 
многократно цитировались как своеобразное кредо путинской генерации крупных собственников, полностью подчиненных власти и управляющих экономикой от ее имени (см., напр. [Shinar 2015, p. 593]). Тем не менее прибыль от бизнеса Дерипаски доставалась именно ему, а не государству: по данным компании «Ренова», только в 2006 г. «Русал» выплатил своему владельцу дивиденды на сумму 4,6 млрд долл. (представитель «Русала» оспорил эту цифру, отказавшись назвать другую) [Симаков 2008]. По другим данным, от всех своих компаний Дерипаска получил в 2005-2008 гг. дивиденды на сумму 8,2 млрд долл. [Кричевский, Иноземцеев 2009]. При этом с наступлением кризиса в 2008 г. «Русал» оказался одним из крупнейших получателей государственной помощи: «Внешэкономбанк» выдал компании кредит на сумму 4,5 млрд долл. При достройке Богучанской ГЭС (совместный проект «Русала» и государственной «Русгидро», отмеченный В.В. Путиным как «очень хороший пример частно-государственного партнерства») «Русал» оказался в двойном выигрыше: срок строительства был перенесен, а достройка ГЭС и Богучанского алюминиевого завода осуществлялась за счет нового кредита «Внешэкономбанка», одобренного в 2010 г. [Первая очередь 2012; Пономарев 2012]. Наконец, в охваченном кризисом Пикалево В.В. Путин подверг О. Дерипаску публичной критике и «заставил» подписать договор с поставщиком принадлежавшего ему предприятия, однако договор, вероятно, согласованный заранее, был выгоден именно О. Дерипаске, поскольку предполагал существенное снижение стоимости сырья для его завода [Баданин, Бочарова, Цветкова, Богушева 2009]. По-видимому, речь идет не столько о подчинении крупного бизнеса государству, сколько о формуле «приватизация выгод, обобществление издержек» [Гельман 2015], пусть скрытой за воинственной риторикой властей.

При наличии явных общих интересов крупный бизнес успешно использует и коллективные лоббистские стратегии. Одна из сфер, в которых это проявляется наиболее ярко, - экологическое регулирование: так, в 2010 г. Д.А. Медведев (на тот момент президент России) поручил принять ряд экологических законов, включая закон, обязывающий промышленников использовать наилучшие доступные технологии (НДТ) с экологической точки зрения. Эта инициатива, предполагающая серьезные траты на модернизацию предприятий, вызвала резкую критику Российского союза промышленников и предпринимателей (РСПП). В результате закон был принят только в 2014 г. после вмешательства В.В. Путина и содержал целый ряд уступок крупному бизнесу: дата начала действия закона была перенесена с 2016 на 2019 г.; количество охваченных им на первом этапе предприятий было сокращено с 11 тыс. до трехсот; бизнес получил право зачесть инвестиции в НДТ против платы за негативное воздействие на окружающую среду, а при внедрении НДТ компенсация за загрязнение окружающей среды полностью отменялась [Martus 2016]. РСПП также лоббировал перенос сроков ратификации Парижского климатического соглашения и противостоял попыткам создать в России систему регулирования выбросов парниковых газов [Давылова 2015].

Все эти примеры успешного индивидуального и коллективного лоббизма свидетельствуют о способности крупных собственников оказывать серьезное влияние на государственную политику, имеющую непосредственное отношение к их бизнес-интересам. В статье будут проанализированы три источника такого влияния: структурная зависимость государства от капитала, информационная асимметрия между ними, а также различные формы инструментальной власти. 


\section{Структурная зависимость и информационная асимметрия}

По мнению ряда исследователей, привилегированное положение бизнеса в капиталистических обществах не сводится к его лоббистским усилиям: оно обеспечивается его непосредственными экономическими функциями, такими как инвестиции и найм рабочей силы. Одним из первых это зафиксировал Р. Милибэнд: «Учитывая степень экономической власти, которой обладает “бизнес-сообщество”, и решающее значение его действий (или бездействия) для ключевых аспектов экономической политики, любое правительство, всерьез намеренное проводить радикальные реформы или попытается присвоить эту власть себе, или обнаружит, что его свобода маневра жестко ограничена требованиями "уверенности бизнеса" [business confidence]» [Miliband 1969, p. 152]. Впоследствии Ф. Блок систематически объяснил действие этого механизма: поскольку представители государства зависят от уровня экономической активности бизнеса (определяющего как объем выплачиваемых налогов, так и общее состояние экономики, которое в свою очередь влияет на предпочтения избирателей), они избегают решений, способных негативно сказаться на уровне инвестиций [Block 1977]. Ч. Линдблом назвал это механизмом «автоматической отдачи», блокирующим невыгодные для бизнеса изменения [Lindblom 1982]. Проанализировав через призму этой теории экономическую политику Индонезии в 1965-1990 гг., Дж. Уинтерс заключил, что авторитарные режимы уязвимы для структурного давления бизнеса наряду с демократическими [Winters 1996]. Он также указал на важность трансграничного движения капитала с точки зрения структурной власти последнего в рамках конкретных национальных юрисдикций.

При этом, по мнению Дж. Уинтерса, структурная зависимость государства от капитала теряет значение, когда политики, даже осознавая важность императива привлечения инвестиций, не способны воплотить его в жизнь в силу «институциональной и организационной слабости» государственных институтов [Winters 1996, p. 40]. Именно так можно охарактеризовать российскую ситуацию 1990-х гг. По словам В. Волкова, «скрытая фрагментация» государства началась еще до распада СССР, при этом «законодательное провозглашение новой российской государственности не остановило процесс структурного разрушения государства, по крайней мере в течение первых пяти-семи лет» [Волков 2012]². Возникшие в этот период олигархические финансово-промышленные группы были хорошо приспособлены к извлечению ренты (но не к производительным инвестициям) в условиях слабого государства, которому они же не давали усилиться посредством уклонения от налогов и коррумпирования государственного аппарата. В силу этих причин взаимодействие крупного бизнеса и руководства страны во второй половине 1990-х гг. представляло собой серию ad hoc сделок в условиях высокой неопределенности.

Ситуация начала меняться после кризиса 1998 г. П. Луонг и Э. Вейнтал демонстрируют, что кризис привел к переосмыслению своих стратегий как бизне-

\footnotetext{
2 Важно отметить, что ослаблению государства способствовал не только процесс перераспределения собственности, начавшийся еще в конце 1980-х гг., но и неолиберальная идеология реформаторов, исключавшая позитивную роль государства в рыночных преобразованиях (см. [Stavrakis 1993; McFaul 1995]).
} 
сом, так и властью. Крупный бизнес обнаружил, что посткризисное восстановление доходов невозможно без инвестиций в реальный сектор, что в свою очередь требует стабильных правил игры, которые может обеспечить только функционирующее государство. Политики же осознали, что наполнение бюджета невозможно без стабильных и увеличивающихся налоговых поступлений от крупного бизнеса. Понимание взаимной зависимости открыло дорогу налоговой реформе, кульминацией которой стало принятие Налогового кодекса в 2001 г., и другим структурным реформам [Luong, Weinthal 2004]. Другими словами, в посткризисный период на первый план выходит именно структурная власть крупного бизнеса, проявляющаяся в осознании политиками зависимости экономического роста (и налоговых поступлений) от созданных для крупных компаний институциональных условий. При этом важно подчеркнуть, что структурная зависимость такого рода стала возможной благодаря изменению стратегических ориентаций не только руководства страны, но и самих крупных собственников в результате внешнего шока (кризиса 1998 г.).

Обратной стороной «равноудаленности» от олигархов, декларируемой В.В Путиным в начале 2000-х гг, стала серия реформ, проведенных в интересах крупного капитала в целом. Егор Гайдар, на тот момент один из лидеров «Союза правых сил», не скрывал: «Одна из причин того, что сегодня либеральные реформы осуществляются довольно успешно, в том, что этот курс соответствует интересам крупного капитала» [Гайдар, Телень 2009]. В результате налоговой реформы были снижены ставки налога на дивиденды и прибыль организаций; кроме того, Россия стала первой в мире крупной страной с плоской шкалой подоходного налога [Appel, Orenstein 2013]. Реформа Трудового кодекса максимально затруднила проведение забастовок и создание независимых профсоюзов. Введение накопительного компонента в рамках пенсионной реформы оказалось подарком для финансового капитала [Markus 2007, p. 299]. Легализация торговли землей в новом Земельном кодексе открыла еще один фронтир для прибыльных инвестиций крупного бизнеса [Visser, Mamonova, Spoor 2012].

Все эти реформы лоббировались Российским союзом промышленников и предпринимателей, который при содействии В.В. Путина превратился в организацию крупного бизнеса. Проведение регулярных встреч с представителями РСПП демонстрировало приоритет, отдававшийся В.В. Путиным крупному капиталу [Yakovlev 2006, p. 1043]. При этом лоббистская активность РСПП была неравномерной: реформам, невыгодным крупному бизнесу, таким как антимонопольная политика, уделялось куда меньше внимания [Guriev, Rachinsky 2005]. Реформы в интересах крупных собственников способствовали авторитарному дрейфу политической системы: трудности в их проведении через Госдуму подтолкнули руководство страны к созданию «Единой России» в качестве новой партии власти, призванной консолидировать влияние исполнительной вертикали в парламенте [Grigoriev, Dekalchuk 2017]. Это еще одно свидетельство в пользу того, что структурная власть бизнеса может вступать в противоречие с демократической политикой [Lindblom 1982].

В то же время дело «Юкоса» ознаменовало новый сдвиг в российской политической экономии. Структурная власть крупного бизнеса, увеличившаяся после кризиса 1998 г., стала вновь сокращаться. У этого процесса было три измерения. Во-первых, государство расширило свое присутствие в нефтегазовом секторе, 
доведя до контрольного пакет акций в «Газпроме» и увеличив активы «Роснефти» за счет добывающих подразделений «Юкоса». В 2000-2008 гг. доля государства в нефтяной промышленности выросла с 10 до 42\% [Rutland 2008, p. 1057]. Во-вторых, в результате реформы налогообложения нефтяного экспорта в 2004 г. государство стало присваивать гораздо большую, чем раньше, долю нефтяной ренты [Appel 2008, p. 311]. В-третьих, с созданием госкорпораций в 2006-2007 гг. государство само начало выступать в качестве инвестора. Таким образом, сократилась зависимость руководства страны от экономических решений, принимаемых крупным бизнесом, а значит, и структурная власть последнего.

Процесс расширения государственного присутствия в экономике в 2004-2008 гг. и сокращения структурной зависимости от крупных собственников был обусловлен несколькими причинами. Наиболее общей можно назвать рост цен на углеводороды, вызвавший обострение конкуренции между государством и капиталом за сырьевую ренту. Дополнительной причиной стало стремление влиятельных представителей путинского ближнего круга удовлетворить свои материальные интересы в госсекторе ${ }^{3}$. Наконец, немаловажен личный фактор Михаила Ходорковского, чья политическая активность противоречила неформальной сделке между В.В. Путиным и крупнейшими бизнесменами, заключенной в 2000 г., и послужила спусковым крючком для изменения правил игры [Guriev, Rachinsky 2005].

И все же, несмотря на дирижистский поворот 2004-2008 гг., крупный капитал оставался ключевым источником инвестиций, которые не могли быть полностью замещены прямым вмешательством государства в экономику. В свою очередь, дополнительным фактором, усиливающим структурное преимущество крупных компаний, выступала их глобальная интеграция, выражавшаяся не только в возможности инвестировать в других юрисдикциях, но и в офшорном характере собственности, упрощавшем вывод капитала. Исследования показывают, что большинство прямых иностранных инвестиций в российскую экономику в действительности представляют собой «возвращающиеся» (roundtripping) инвестиции российских компаний из офшорных зон, таких как Кипр, Сейшелы и Британские Виргинские острова [Ledyaeva, Karhunen, Kosonen, Whalley 2015].

Чтобы привлечь эти инвестиции, государство все больше полагалось на разветвленную систему льгот и преференций, включая софинансирование от государственных банков, госгарантии по кредитам, налоговые и таможенные льготы, а также специальный налоговый режим и привилегированный доступ к инфраструктуре в особых экономических зонах (ОЭЗ). Журнал «Эксперт», с 2010 г. публиковавший ежеквартальные обзоры всех крупных инвестиционных проектов в России, спустя год наблюдений обнаружил, что лишь $25 \%$ из них «можно считать абсолютно естественными и не привязанными к деятельности государства по стимулированию в стране инвестиционного процесса» [Лебедев, Сиваков 2011]. Общий масштаб российской версии corporate welfare, «социальной поддержки» бизнеса государством, оценить трудно, однако ясно, что он крайне велик. На одни

\footnotetext{
3 Одним из первых это зафиксировал Г. Павловский в аналитической записке «О негативных последствиях «летнего наступления» оппозиционного курсу президента РФ меньшинства» (2003).
} 
только особые экономические зоны в период 2006-2015 гг., по данным Счетной палаты, было потрачено 185,9 млрд руб. бюджетных средств. Потери консолидированного бюджета от налоговых льгот в 2014-2017 гг. составили в среднем $2,7 \%$ ВВП, при этом более $80 \%$ потерь пришлось на льготы в рамках поддержки экономики.

Структурная зависимость от капитала проявляется не только в конкуренции российской экономики с другими юрисдикциями, но и во внутренней конкуренции регионов между собой: пытаясь привлечь инвестиции, они вводят свои собственные льготы, что негативно сказывается на их бюджетах наряду с социальными обязательствами, перекладываемыми на них федеральным центром. Так, в 2006 г. ставка налога на прибыль в Пермском крае была снижена на 4\%, в 2009 г. - еще на $0,5 \%$. В результате применения этой льготы, по данным краевой Счетной палаты, выпадающие доходы регионального бюджета в 2006-2013 гг. составили 69,1 млрд руб. (или $15 \%$ от всех бюджетных поступлений за этот период). Региональные власти не скрывают, что основным мотивом для введения льготы было удержание компании «Лукойл» и других крупных фирм в налоговой юрисдикции региона: «<...> чтобы удержать собственное предприятие от смены места уплаты налога на прибыль, мы сработали достаточно хорошо. Абсолютно понятно, что ОАО «ЛУКОЙЛ» - компания, для которой любой регион на сегодняшний день готов предоставить любую налоговую льготу. И если мы лишим его такой возможности на родной территории. $<\ldots .>$ У бизнеса, как известно, с чувством родины проблемы. То есть у него родина там, где выгодно» [Суханов 2010].

Дополнительным преимуществом крупного бизнеса, обусловленным самим характером его экономической деятельности, является информационная асимметрия между государством и капиталом. Действуя на рынке, бизнес обладает привилегированным доступом к информации о его состоянии, которого лишены политики и чиновники, что позволяет ему, с одной стороны, использовать информацию в качестве «входного билета» при получении доступа к разработке государственной политики, с другой, лоббировать выгодные для себя решения, которые, возможно, не были приняты, если бы политики и чиновники обладали тем же уровнем информированности, что и бизнесмены [Bernhagen, Bräuninger 2005].

Информация является одним из ключевых лоббистских ресурсов и в российском случае. По словам представителя розничной компании X5 Retail Group, «проблема в том, что наши госструктуры, которые отвечают за подготовку проектов решений, недоинформированы. < .. > [Данные] есть у нас, больших корпораций, тех, кто постоянно находится во взаимодействии с конечным потребителем» [Бекбулатова 2017]. Другие лоббисты, процитированные в статье Т. Бекбулатовой, также указывают на зависимость государства от экспертизы частного бизнеса, что согласуется с теорией информационной асимметрии государства и капитала. По словам А. Зудина, с начала 2000-х гг. на федеральном уровне постоянно возрастает спрос на информацию и экспертизу со стороны крупных частных фирм и бизнес-ассоциаций; этот спрос уравновешивает нормотворческую власть министерств и ведомств [Зудин 2013, с. 7]. 


\section{Инструментальная власть}

Структурная зависимость государства от капитала обеспечивает последнему преимущество, которое, однако, не является абсолютным: государственная политика определяется различными факторами, такими как политическое представительство и потенциал коллективной мобилизации социальных групп, внутрикорпоративные интересы бюрократии и т.д. Эти факторы действуют как имплицитно (оказывая эффект наряду со структурной зависимостью от капитала на установки политиков и чиновников), так и эксплицитно (в форме открытых или скрытых лоббистских усилий). На практике это означает, что у руководства страны есть выбор, и выгодный бизнесу результат в каждом конкретном случае не гарантирован [Culpepper 2015; Swank 1998]. Это побуждает бизнес проявлять целенаправленную активность, не связанную с его непосредственными экономическими функциями: заниматься индивидуальным и коллективным лоббизмом, финансировать избирательные кампании, поощрять практику «вращающихся дверей» (обмен персоналом между фирмами и государственными структурами), а также участвовать в прямой коррупции. Активность такого рода - источник инструментальной власти бизнеса, дополняющей его структурную власть в капиталистических обществах. Преимуществом бизнеса в данном случае являются финансовые ресурсы, несопоставимые с ресурсами других социальных групп. Высокий уровень инструментальной власти бизнеса и отражает ситуацию «захвата государства» (state capture).

В этой перспективе инструментальная власть олигархических финансовопромышленных групп во второй половине 1990-х гг. была крайне высокой и проявлялась в привилегированном доступе к руководству страны вплоть до первого лица (в ряде случаев олигархи сами занимали высокие посты на федеральном уровне), исключительном влиянии на публичную политику за счет контроля над СМИ и финансирования партий, а также в коррупционной «приватизации» частей госаппарата ${ }^{4}$. Вопреки формуле К. Маркса, «современная государственная власть - это только комитет, управляющий общими делами всего класса буржуазии» [Маркс, Энгельс 1955, с. 425], российское государство во второй половине 1990-х гг. не столько управляло общими делами крупных собственников, сколько было разделено ими на сферы влияния и становилось инструментом в их конфликтах.

Как уже было сказано, кризис 1998 г. создал возможность для пересмотра этого формата отношений, и с приходом В.В. Путина к власти эти изменения были закреплены. Федеральная бюрократия консолидировала свою финансовую и организационную базу, а отношения с олигархами были формализованы в рамках встреч с РСПП. По точному замечанию Саймона Пирани, «государство дисциплинировало олигархов в интересах класса собственников в целом» [Pirani 2010, p. 1]. Автономизация государства на федеральном уровне позволила ему приблизиться к марксовой формуле, из орудия отдельных буржуа превратившись в «коми-

\footnotetext{
4 Обзор политической активности ключевых финансово-промышленных групп в 1990-е гг. дан в книге Якова Паппэ [Паппэ 2000].
} 
тет, управляющий общими делами всего класса буржуазии» ${ }^{5}$. Другими словами, сокращение инструментальной власти крупного бизнеса на федеральном уровне компенсировалось ростом его структурной власти; более того, без сокращения инструментальной власти рост структурной власти был бы невозможен.

В то же время на региональном уровне в 2000-2003 гг. наблюдалась своя собственная динамика. Посткризисная экспансия крупных собственников в реальный сектор толкала их к борьбе за региональные активы, в которой зачастую использовались те же практики «захвата государства», что и на федеральном уровне в 1990-е гг. [Orttung 2004]. При этом, по замечанию Роберта Орттунга, интересы Кремля и крупных компаний ситуативно совпадали: приход в регионы федерального бизнеса разрушал связку между местными политическими и экономическими элитами, тем самым ослабляя губернаторов и способствуя путинской политике рецентрализации [Orttung 2004, p. 51]. Другим каналом влияния олигархов оставалась Госдума: на парламентских выборах 1999 г. олигархические группы успешно продвигали своих кандидатов в одномандатных округах, что позволило им в 2000-2003 гг. задерживать или полностью блокировать в Думе некоторые правительственные инициативы [Hale 2005; Tompson 2005].

Тем не менее вследствие нового сдвига в российской политической экономии после дела «Юкоса» не только сократилась структурная зависимость государства от крупного капитала, но и произошли изменения в характере инструментальной власти последнего. В период второго срока В.В. Путина исполнительная вертикаль установила жесткий контроль над парламентом; при этом снизились лоббистские возможности бизнеса в Думе [Chaisty 2012]. Участие крупного капитала в региональной политике также сократилось: после дела «Юкоса» оно, как и участие в федеральной политике, стало опасным; основной этап перераспределения активов в регионах к 2003 г. подошел к концу; наконец, вследствие курса на рецентрализацию, проводимого Кремлем, региональный уровень потерял свое значение по сравнению с федеральным [Туровский 2005].

В то же время в распоряжении крупного бизнеса остался ряд формальных каналов влияния, таких как РСПП, с представителями которого В.В. Путин попрежнему проводил регулярные встречи. Бизнес и государство взаимодействовали на множестве площадок, таких как сформированная в 2012 г. комиссия по ТЭК при президенте России, в которую наряду с чиновниками вошли руководители крупнейших нефтяных компаний - как государственных, так и частных. В ряде случаев бизнесмены были представлены в советах директоров госкорпораций (Владимир Лисин состоял в совете директоров Объединенной судостроительной корпорации в 2008-2012 гг., в 2011-2012 гг. был председателем СД; В. Вексельберг в совете директоров «Роснано» - с 2015 г. по настоящее время).

Кроме того, потеря одних неформальных источников влияния отчасти компенсировалась приобретением других: так, в период второго путинского срока «равноудаленность» от олигархов сменилась растущим влиянием особо приближенных к В.В. Путину бизнесменов - Г. Тимченко, А. и Б. Ротенбергов,

\footnotetext{
5 По словам Р. Милибенда, знаменитое марксово определение государства в «Манифесте Коммунистической партии» неверно интерпретируется в духе полного подчинения государства буржуазии: управление общими делами класса, в отличие от частных дел отдельных его представителей, само по себе предполагает относительную автономию по отношению к требованиям каждого из них [Miliband 1973, p. 85].
} 
Ю. Ковальчука ${ }^{6}$. Союз с ними позволял приобрести могущественных лоббистов на самом высоком уровне: так, в ситуации, когда во второй половине 2000-х гг. газовая компания «Новатэк» оказалась под угрозой поглощения «Газпромом» (с другими независимыми производителями газа «Итерой» и «Нордгазом» это уже произошло), владелец «Новатэка» Л. Михельсон продал долю в компании Г. Тимченко. После того как последний вошел в капитал «Новатэка», компания не только сохранила независимость, но и многократно увеличила запасы. В 2010 г. Л. Михельсон и Г. Тимченко выкупили у «Газпромбанка» крупнейшую нефтехимическую компанию страны «Сибур», господряды дочерних структур которой позволили Л. Михельсону войти в рейтинг Forbes «Короли госзаказа» [Мокроусова, Тодорова 2016; Короли госзаказа 2016], а в 2016 г. Л. Михельсон возглавил российский рейтинг Forbes (14,4 млрд долл.).

Пример Л. Михельсона не единственный. С середины 2000-х гг. крупные собственники систематически налаживали связи с узкой группой предпринимателей из окружения В.В. Путина: так, согласно данным из открытых источников, на конец 2017 г. Г. Тимченко, А. и Б. Ротенберги, Ю. Ковальчук имели совместный бизнес не менее чем с шестью другими миллиардерами из российского рейтинга Forbes за соответствующий год: Л. Михельсоном, И. Махмудовым, А. Бокаревым, А. Пономаренко, А. Скоробогатько и А. Мордашовым (их деловые отношения отражены на рисунке 2). К бизнесменам, тесно связанным с предпринимателями из путинского ближнего круга, также следует отнести С. Керимова ${ }^{7}$, В. Богданова ${ }^{8}$ и В. Анисимова ${ }^{9}$. Таким образом, с близкими к В.В. Путину бизнесменами были связаны 9 из 96 российских миллиардеров по версии Forbes в 2017 г. Кроме того, в числе деловых партнеров Г. Тимченко, А. и Б. Ротенбергов и Ю. Ковальчука присутствовал ряд крупных собственников, не попавших в российский рейтинг Forbes.

Вокруг Г. Тимченко, А. и Б. Ротенбергов и Ю. Ковальчука сформировался один из главных (хотя и не единственный) полюсов «политического капитализма» в современной России: не только они сами (за исключением Ю. Ковальчука), но и их деловые партнеры - Л. Михельсон, А. Мордашов, И. Махмудов и А. Бокарев регулярно оказывались в списке «Королей госзаказа» Forbes. Ряд исследований косвенным образом подтверждают, что стратегия «политического накопления» оказывается для российского крупного бизнеса выгоднее стратегии «рыночного накопления» ${ }^{10}$ : так, Н. Ламберова и К. Сонин обнаружили, что состояние участников российского рейтинга Forbes, чьи имена хотя бы один раз упоминались в новостном сюжете вместе с именами представителей ближнего круга В.В. Путина (в который, по их версии, входили 24 чел.), росло в среднем на 800 млн долл. в год быстрее, чем состояние остальных крупных собственников, хотя этот эффект и наблюдался только в период высоких цен на нефть [Lamberova, Sonin 2018].

\footnotetext{
6 В 2014 г. во время прямой линии В.В. Путин публично признал их своими друзьями [Прямая линия с Владимиром Путиным 2014].

7 В 2012 г. он разместил в принадлежащем А. и Б. Ротенбергам «СМП Банке» депозит на 100 млн долл.; кроме того, С. Керимов и А. Ротенберг какое-то время владели гостиницей «Москва».

8 В 2002-2012 гг. Г. Тимченко контролировал компанию «Сургутэкс», торговавшую нефтепродуктами «Сургутнефтегаза», возглавляемого В. Богдановым.

9 Строительная компания В. Анисимова Coalco наряду с «СМП Банком» А. и Б. Ротенбергов выступала официальным партнером Федерации дзюдо России; В. Анисимов - президент Федерации, А. Ротенберг - ее вицепрезидент.

10 О «политическом накоплении» в российском капитализме см. [King 2002].
} 
В свою очередь, Ю. Агафонов и В. Лепеле отмечают, что крупные собственники, создавшие свой бизнес с нуля без использования политических связей, оказались в наиболее уязвимом положении в период кризиса 2008-2009 гг., что также свидетельствует о преимуществе стратегии «политического накопления» в российских условиях [Агафонов, Лепеле 2016].

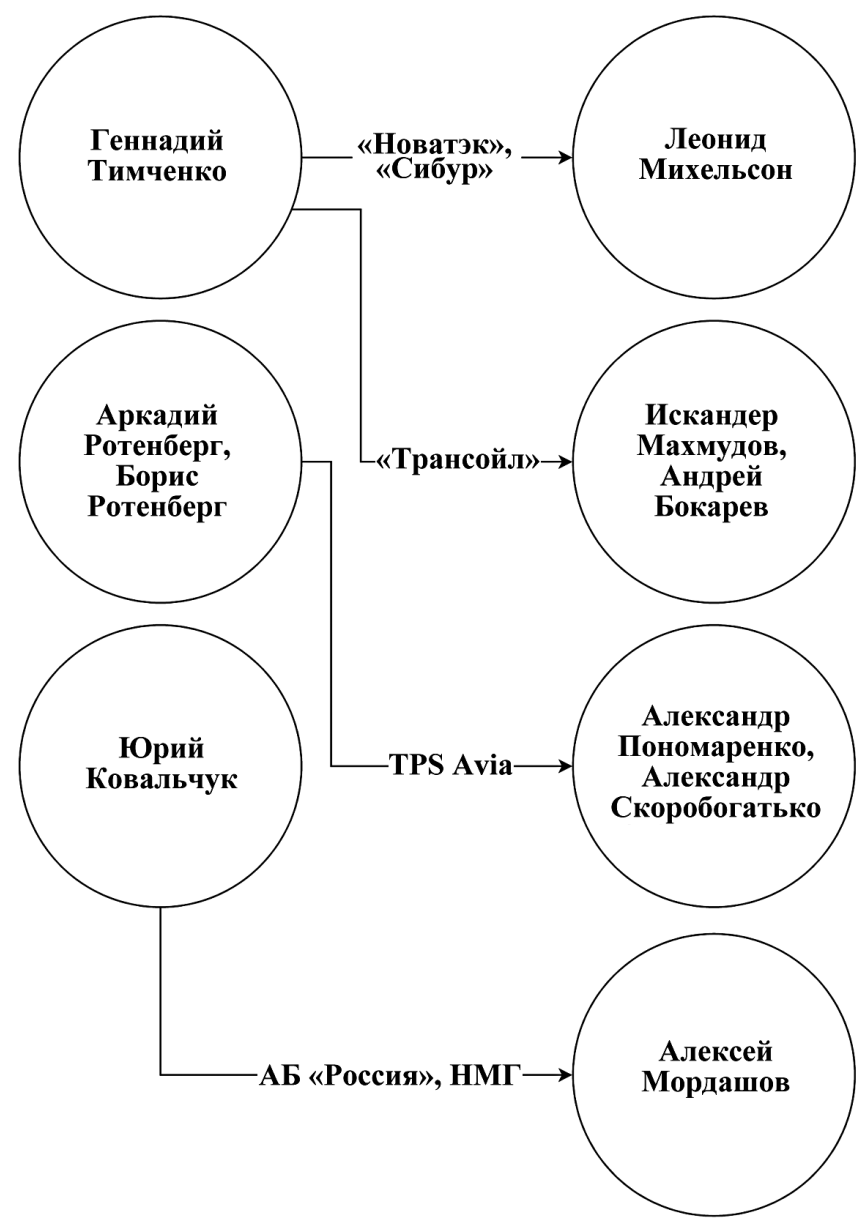

Рисунок 2. Совместный бизнес предпринимателей из окружения В.В. Путина и других участников российского рейтинга Forbes

В то же время исследование Ю. Агафонова и В. Лепеле рисует более сложную картину российского крупного бизнеса, чем принято считать: так, их анализ рейтинга Forbes показывает, что в целом в 2005-2015 гг. «доля тех, кто начал свой бизнес без какого-либо существенного использования административного ресурса и конкурентных преимуществ переходного политического и экономического 
периода, выросла почти на 11\%» [Агафонов, Лепеле 2016, с. 119]. Другими словами, в этот период стратегия «рыночного накопления» пусть медленно, но утверждалась в сфере крупного бизнеса. Следует отметить, что крупный капитал обладает важным преимуществом независимо от того, характеризуется ли он стратегией политического или рыночного накопления: его права собственности защищены куда лучше, чем права собственности среднего и малого бизнеса. Так, Д. Трейсман обнаружил, что из 63 бизнесменов, покинувших рейтинг миллиардеров Forbes в 2006-2015 гг., всего двое лишились этого статуса по причинам, хотя бы частично связанным с давлением государства; в остальных случаях причины были экономическими [Treisman 2016, p. 240]. В то же время для малого и среднего бизнеса давление чиновников и особенно силовиков в этот же период стало ключевой угрозой [Gans-Morse 2012].

\section{Крупный бизнес и демократическое представительство}

Структурная зависимость государства от капитала, информационная асимметрия между ними, а также различные формы инструментальной власти бизнеса характерны как для демократий, так и для авторитарных режимов при условии, что частная собственность играет в них сколько-нибудь значимую роль. Однако характер ограничений, налагаемых на власть бизнеса, в демократиях и автократиях различается: так, по версии Б. Джессопа, основным противоречием капиталистических демократий является диссонанс между «политикой поддержки» (необходимостью добиваться голосов населения на выборах) и «политикой власти» (объективными ограничениями, накладываемыми на политических игроков самой природой капиталистических обществ, прежде всего, структурной зависимостью от капитала). Это противоречие создает определенную дистанцию между политикой государства и интересами капиталистического класса, хотя и может в конечном счете оказаться продуктивным для стабилизации долговременного господства последнего [Jessop 1978]. Кроме того, свобода объединения в демократических обществах предполагает возможность коллективной мобилизации социальных групп, которая в свою очередь способна не только влиять на электоральную политику, но и непосредственно угрожать накоплению капитала (к примеру, в форме забастовок).

В противоположность этому российский политический режим, не избавляясь полностью от демократических процедур, последовательно сокращал их представительный характер, что дало основание одним исследователям назвать его «гибридным» [Hale 2010], другим - режимом «электорального авторитаризма» [Голосов 2008]. Возможности коллективной мобилизации также были ограничены, свобода объединения регулярно нарушалась. На практике это означает, что выработка государственной политики в России с начала 2000-х гг. происходила едва ли не исключительно под влиянием элитных акторов, тогда как интересы широких слоев населения были представлены лишь имплицитно в форме стремления руководства страны поддерживать «социальную стабильность» [Petrov, Lipman, Hale 2014]. В то же время интересы крупного бизнеса присутствовали как имплицитно в форместруктурнойзависимостигосударстваоткапитала, такиэксплицитно 
с помощью формальных и неформальных каналов влияния. Этим и объясняется привилегированное положение крупного бизнеса в России 2000-х - 2010-х гг. Разумеется, его доминирование не является абсолютным: интересы крупных собственников нередко вступают в конфликт с интересами других представителей элиты, к примеру, руководителей государственных компаний. Однако связанные с этим издержки могут оказаться ниже, чем издержки в условиях институционализированного демократического представительства. Тактика популярного оппозиционного политика Алексея Навального в период избирательного цикла 2017-2018 гг. свидетельствует о том, что демократизация в России с большой долей вероятности будет сопровождаться атаками на крупных собственников (особенно связанных с властью) и мощными перераспределительными требованиями.

\section{Заключение: 2014 год и далее}

Задачей этой статьи было показать, что подчинение крупного бизнеса государству в путинский период относится скорее к риторике властей и самих крупных собственников, чем к реальному положению дел. При взаимодействии с государством российский крупный бизнес имеет ряд преимуществ, в числе которых структурная зависимость государства от капитала, усиленная глобальной интеграцией и офшорным характером собственности крупных компаний, информационная асимметрия между бюрократией и бизнесом, позволяющая последнему использовать информацию и экспертизу в качестве лоббистского ресурса, формальные и неформальные каналы влияния, в частности, деловые связи с предпринимателями из окружения В.В. Путина. Все эти факторы объясняют стремительный рост числа российских миллиардеров и их совокупного состояния с начала 2000-х гг., свидетельствующий о благоприятных условиях для накопления капитала. Когда такие условия существуют, попытки бизнесменов играть роль «серых кардиналов» при власти, характерные для 1990-х гг., оказываются совершенно ненужными.

В то же время события 2014 г., вполне возможно, открыли новую страницу в истории отношений крупного бизнеса и власти в России. В период до 2014 г. руководство страны зачастую шло на конфликт с отдельными крупными собственниками, но избегало политики, способной поставить под угрозу интересы крупного капитала в целом. Однако новый виток конфронтации с Западом является примером именно такой политики. Внешнеполитический фактор не только снижает критически важную для российского крупного бизнеса способность привлекать средства на Западе, но и делает уязвимыми его зарубежные активы и рынки сбыта, что в свою очередь заставляет крупный бизнес искать поддержки у российских властей, тем самым повышая свою зависимость от последних. Кроме того, структурная власть капитала сокращается, поскольку ключевую роль в рамках государственной системы приобретают органы, отдающие приоритет не инвестициям и экономическому росту, а борьбе с внешними и внутренними угрозами, секьюритизации всех аспектов государства и общества. Так, по словам А. Яковлева, в 2008-2012 гг. центр принятия решений находился в правительстве, 
в 2012-2013 гг. - в администрации президента, однако с 2014 г. центр принятия решений переместился в Совет безопасности, - орган, для которого вопросы накопления капитала не являются приоритетными [Яковлев 2015].

Непосредственной причиной такой автономизации российского государства от бизнес-интересов, по-видимому, являются события 2013-2014 гг. на Украине, оцененные российскими руководством как чрезвычайные и требующие экстраординарной реакции. Однако на более общем уровне новая политика Кремля, во многом противоречащая интересам крупных собственников, уходит корнями в политические изменения третьего срока В.В. Путина: с 2012 г. идеологическая мобилизация постепенно заменяет экономический рост в качестве основного источника легитимности режима [Матвеев 2017], что позволяет руководству страны ослабить структурную зависимость от капитала. Тем не менее в обозримой перспективе экономические проблемы вполне могут принять угрожающий характер и заставить режим стать более отзывчивым к интересам крупного бизнеса, вплоть до корректировки внешнеполитического курса. Пока же российское государство целенаправленно сглаживает последствия этого курса для крупных собственников, оказывая им поддержку в различных формах.

\section{Литература}

Агафонов Ю., Лепеле В. (2016) «Золотые двери» в российскую бизнес-элиту: рекрутирование и изменение структуры крупного предпринимательства в постсоветской России // Мир России. № 3. С. 97-125.

Баданин Р., Бочарова С., Цветкова М., Богушева Е. (2009) Для людей и Дерипаски // Газета. ru. 4 июня 2009// https://www.gazeta.ru/politics/2009/06/04 a 3206790.shtml

Бекбулатова Т. (2017) Их не видно, но они решают вопросы // Mēuza.io. 21 декабря 2017 // https://meduza.io/feature/2017/12/21/ih-ne-vidno-no-oni-reshayut-voprosy

Белтон К. (2007) «Мне не от чего защищаться» // Иносми.ру. 13 июля 2017 // https://inosmi.ru/inrussia/20070713/235517.html

Волков В. (2012) Силовое предпринимательство, XXI век: экономико-социологический анализ. СПб.: Европейский университет в Санкт-Петербурге.

Гайдар Е., Телень Л. (2009) Свою повинность отбыл // Московские новости. 16 декабря 2009 // https://www.svoboda.org/a/1905525.html

Гельман В. (2015) Модернизация, институты и «порочный круг» постсоветского неопатримониализма. СПб.: Европейский университет в Санкт-Петербурге.

Голосов Г. (2008) Электоральный авторитаризм в России // Pro et Contra. T. 12. № 1. C. 22-35.

Давыдова А. (2015) РСПП добился перемены в климате // Коммерсант.ru. 22 декабря 2015 // https://www.kommersant.ru/doc/2882957

Зудин А. (2013) Государство и бизнес в России (Опыт применения концепции НортаУоллиса-Вайнгаста). Статья 2. Тенденции развития отношений между государством и бизнесом // Общественные науки и современность. № 3. С. 5-17.

Короли госзаказа-2016: рейтинг Forbes (2016) // Forbes. 25 февраля 2016 // http://www.forbes.ru/rating-photogallery/313039-koroli-goszakaza-2016-reiting-forbes

Кричевский Н., Иноземцев В. (2009) Экономикой правят олигархи // Ведомости. 17 августа 2009 // https://www.vedomosti.ru/opinion/articles/2009/08/17/ jekonomikoj-pravyat-oligarhi

Лебедев В., Сиваков Д. (2011) Инвестиции на ручном управлении // Эксперт. 11 апреля 2011 // http://expert.ru/expert/2011/14/nvestitsii-na-ruchnom-upravlenii/ 
Маркс К., Энгельс Ф. (1955) Сочинения. М.: Государственное издательство политической литературы. Изд. 2-е.

Матвеев И. (2017) Конец «стабильности»: политическая экономия пересекающихся кризисов в России с 2009 года // Социологическое обозрение. Т. 16. № 2. С. 29-53.

Мокроусова И., Тодорова М. (2016) Полезные ресурсы // Forbes. 3 мая 2016 // http://www.forbes.ru/forbes/issue/2016-05/317605-poleznye-resursy

Павловский Г. (2003) О негативных последствиях «летнего наступления» оппозиционного курсу президента РФ меньшинства // Новая газета. 2 сентября 2003 // http://2003.novayagazeta.ru/nomer/2003/67n/n67n-s00.shtml

Паппэ Я. (2000) «Олигархи». Экономическая хроника 1992-2000. М.: ВШЭ.

Паппэ Я., Галухина Я. (2009) Российский крупный бизнес: первые 15 лет экономические хроники, 1993-2008. М.: ВШЭ.

Первая очередь Богучанской ГЭС запущена в техническую эксплуатацию (2012) // Kremlin.ru. 15 октября 2012 // http://kremlin.ru/events/president/news/16643

Пономарев В. (2012) Последний долгострой // Эксперт.Online.ru // http://expert.ru/siberia/2012/42/poslednij-dolgostroj_2/

Прямая линия с Владимиром Путиным (2014) // Kremlin.ru. 17 апреля 2014 // http://kremlin.ru/events/president/news/20796

Симаков Д. (2008) За 2006 г. Дерипаска получил от «Русала» \$4,6 млрд дивидендов, сообщила «Ренова» Вексельберга // Компромат.ru. 15 января 2008 // http://www.compromat.ru/page 22042.htm

Становая Т. (2017) Политика догоняет. О чем не сказал Михаил Фридман // Republic.ru. 10 января 2017 // https://republic.ru/posts/88831

Струченевский А. (2016) Крупный бизнес наносит ответный удар // Стратегические решения и риск-менеджмент. № 6. С. 48-53.

Суханов В. (2010) Я бы запретила публичные попытки отменить льготу по налогу на прибыль // Коммерсант.ru. 23 сентября 2010 // https://www.kommersant.ru/doc/1508519

Туровский Р. (2005) Власть и бизнес в регионах России: современные процессы обновления региональной элиты // Фрухтманн Я. (ред.) Региональная элита в современной России. М.: Фонд «Либеральная миссия». С. 160-169.

Яковлев А. (2015) Смысл и назначение воинственности // Россия в глобальной политике. T. 13. № 6. C. 119-134.

Appel H. (2008) Is It Putin or Is It Oil? Explaining Russia's Fiscal Recovery // Post-Soviet Affairs, vol. 24, no 4, pp. 301-323.

Appel H., Orenstein M. (2013) Ideas Versus Resources Explaining the Flat Tax and Pension Privatization Revolutions in Eastern Europe and the Former Soviet Union // Comparative Political Studies, vol. 46, no 2, pp. 123-152.

Bernhagen P., Bräuninger T. (2005) Structural Power and Public Policy: A Signaling Model of Business Lobbying in Democratic Capitalism // Political Studies, vol. 53, no 1, pp. 43-64.

Block F. (1977) The Ruling Class Does Not Rule: Notes on the Marxist Theory of the State // Socialist Revolution, vol. 33, no 7, pp. 6-28.

Chaisty P. (2012) Business Representation in the State Duma // Waiting for Reform under Putin and Medvedev (eds. Jonson L., White S.), Palgrave Macmillan, pp. 140-158.

Culpepper P. (2015) Structural Power and Political Science in the Post-crisis Era // Business and Politics, vol. 17, no 3, pp. 391-409.

Duvanova D. (2011) Firm Lobbying Versus Sectoral Organization: The Analysis of Businessstate Relations in Post-communist Russia // Post-Soviet Affairs, vol. 27, no 4, pp. 387-409.

Gans-Morse J. (2012) Threats to Property Rights in Russia: From Private Coercion to State Aggression // Post-Soviet Affairs, vol. 28, no 3, pp. 263-295.

Hale H. (2005) Why not Parties in Russia?: Democracy, Federalism, and the State, Cambridge University Press.

Hale H. (2010) Eurasian Polities as Hybrid Regimes: The Case of Putin's Russia // Journal of Eurasian Studies, vol. 1, no 1, pp. 33-41.

Jessop B. (1978) Capitalism and Democracy: the Best Possible Political Shell // Power and the State (eds. Littlejohn G., Smart P., Wakeford J., Yuval Davis N.), London: Croom Helm, pp. $10-51$. 
King L. (2002) Postcommunist Divergence: a Comparative Analysis of the Transition to Capitalism in Poland and Russia // Studies in Comparative International Development, vol. 37, no 3, pp. 3-34.

Lamberova N., Sonin K. (2018) The Role of Business in Shaping Economic Policy // The New Autocracy: Information, Politics, and Policy in Putin's Russia (ed. Treisman D.), Washington, D.C.: Brookings Institution Press.

Ledyaeva S., Karhunen P., Kosonen R., Whalley J. (2015) Offshore Foreign Direct Investment, Capital Round-tripping, and Corruption: Empirical Analysis of Russian Regions // Economic Geography, vol. 3, no 91, pp 305-341.

Lindblom C. (1982) The Market as Prison // The Journal of Politics, vol. 44, no 2, pp. 324-336.

Luong P., Weinthal E. (2004) Contra Coercion: Russian Tax Reform, Exogenous Shocks, and Negotiated Institutional Change // American Political Science Review, vol. 98, no 1, pp. 139-152.

Markus S. (2007) Capitalists of All Russia, Unite! Business Mobilization under Debilitated Dirigisme // Polity, vol. 39, pp. 277-304.

Martus E. (2017) Contested Policymaking in Russia: Industry, Environment, and the "Best Available Technology" Debate // Post-Soviet Affairs, vol. 33, no 4, pp. 276-297.

McFaul M. (1995) State Power, Institutional Change, and the Politics of Privatization in Russia // World Politics, vol. 47, no 2, pp. 210-243.

Miliband R. (1969) The State in Capitalist Society, New York: Basic Books.

Miliband R. (1973) Poulantzas and the Capitalist State // New Left Review, no 82, pp. 83-92.

Müller M. (2011) State Dirigisme in Megaprojects: Governing the 2014 Winter Olympics in Sochi // Environment and Planning A, vol. 43, no 9, pp. 2091-2108.

Orttung R. (2004) Business and Politics in the Russian Regions // Problems of Post-Communism, vol. 51, no 2, pp. 48-60.

Petrov N., Lipman M., Hale H. (2014) Three Dilemmas of Hybrid Regime Governance: Russia from Putin to Putin // Post-Soviet Affairs, vol. 30, no 1, pp. 1-26.

Pirani S. (2010) Change in Putin's Russia: Power, Money and People, Pluto Press.

Rutland P. (2008) Putin's Economic Record: Is the Oil Boom Sustainable? // Europe-Asia Studies, vol. 60 , no 6 , pp. 1051-1072.

Shinar C. (2015) The Russian Oligarchs, from Yeltsin to Putin // European Review, vol. 23, no 4, pp. 583-596.

Stavrakis P. (1993) State Building in post-Soviet Russia: The Chicago Boys and the Decline of Administrative Capacity, Kennan Institute for Advanced Russian Studies. The Wilson Center.

Swank D. (1998) Funding the Welfare State: Globalization and the Taxation of Business in Advanced Market Economies // Political Studies, vol. 46, no 4, pp. 671-692.

Thompson W. (2005) Putin and the "Oligarchs": A Two-Sided Commitment Problem // Leading Russia: Putin in Perspective: Essays in Honour of Archie Brown (ed. Pravda A.), Oxford: Oxford University Press, pp. 179-202.

Treisman D. (2016) Russia's Billionaires // American Economic Review, vol. 106, no 5, pp. 236-241.

Visser O., Mamonova N., Spoor M. (2012) Oligarchs, Megafarms and Land Reserves: Understanding Land Grabbing in Russia // The Journal of Peasant Studies, vol. 39, no 3-4, pp. 899-931.

Winters J. (1996) Power in Motion: Capital Mobility and the Indonesian State, New York: Cornell University Press.

Yakovlev A. (2006) The Evolution of Business: State Interaction in Russia: From State Capture to Business Capture? // Europe-Asia Studies, vol. 58, no 7, pp. 1033-1056. 


\title{
Large Business in Putin's Russia: Old and New Sources of Power and Influence
}

\section{MATVEEV*}

\begin{abstract}
*Ilya Matveev - PhD in Politics, Assistant Professor, Department of Comparative Political Studies, North-West Institute of Management RANEPA. Address: 57/43, Srednij Lane, V.O., Saint Petersburg, 199178, Russian Federation. E-mail: matveev.ilya@yahoo.com
\end{abstract}

Citation: Matveev I. (2019) Large Business in Putin's Russia: Old and New Sources of Power and Influence. Mir Rossii, vol. 28, no 1, pp. 54-74 (in Russian). DOI: 10.17323/1811-038X-2019-28-1-54-74

\begin{abstract}
The dominant scholarly view of large business in Putin's Russia is that it is completely subordinate to the state. Researchers point out that big business is implicitly kept away from financing any political opposition and is required to invest in projects that are important for the authorities. However, the rapid growth of the number of Russian billionaires and their cumulative wealth during the 2000s and the 2010s indicate that the institutional and political setup in Russia is in fact quite favorable for big business. This article maintains that the picture of the political influence of large business is incomplete without taking into account such factors as the structural power of capital (the state's dependence on the economic decisions of private companies), information asymmetry (big business's advantage in information and expertise) and the instrumental power of capital (formal and informal channels of influence). While in the 1990s large businesses had very high instrumental power and low structural power, in the 2000s and the 2010s structural power takes center stage: the authorities implemented pro-business policies in order to maintain investment and economic growth. Large companies have acquired new sources of political influence, such as ties with businessmen from Putin's inner circle. According to data from open sources, 9 out of 96 billionaires from the 2017 Russian Forbes list have or had extensive business ties with four businessmen close to Putin. All these factors allow large Russian companies to be assertive in their relationship with the state and engage in successful lobbying activities.
\end{abstract}

Key words: large business, the state, lobbyism, informal ties, structural dependence, information asymmetry

\section{References}

Agafonov Yu., Lepele V. (2016) «Zolotye dveri» v rossijskuyu biznes-elitu: rekrutirovanie i izmenenie struktury krupnogo predprinimatel'stva v postsovetskoj Rossii [The "Golden Doors" to the Russian Business Elite: the Recruitment Process and the Structural Transformation of Largescale Business in Post-Soviet Russia]. Mir Rossii, no 3, pp. 97-125. 
Appel H. (2008) Is It Putin or Is It Oil? Explaining Russia’s Fiscal Recovery. Post-Soviet Affairs, vol. 24, no 4, pp. 301-323.

Appel H., Orenstein M. (2013) Ideas Versus Resources Explaining the Flat Tax and Pension Privatization Revolutions in Eastern Europe and the Former Soviet Union. Comparative Political Studies, vol. 46, no 2, pp. 123-152.

Badanin R., Bocharova S., Tsvetkova M., Bogusheva E. (2009) Dlya lyudej i Deripaski [For the People and for Deripaska]. Gazeta.ru, June 9, 2009. Available at: https://www.gazeta.ru/politics/2009/06/04 a 3206790.shtml, accessed 27.09.2018.

Bekbulatova T. (2017) Ikh ne vidno, no oni reshayut voprosy [They Are Out of Sight, Yet They Get Things Done]. Meduza.io, December 21, 2017. Available at: https://meduza. io/feature/2017/12/21/ih-ne-vidno-no-oni-reshayut-voprosy, accessed 27.09.2018.

Belton K. (2007) «Mne ne ot chego zashchishchat'sya» ["I Do not Have to Defend Myself from Anything”]. Inosmi.ru, July 13, 2017. Available at: https://inosmi.ru/inrussia/20070713/235517.html, accessed 27.09.2018.

Bernhagen P., Bräuninger T. (2005) Structural Power and Public Policy: A Signaling Model of Business Lobbying in Democratic Capitalism. Political Studies, vol. 53, no 1, pp. 43-64.

Block F. (1977) The Ruling Class Does Not Rule: Notes on the Marxist Theory of the State. Socialist Revolution, vol. 33, no 7, pp. 6-28.

Chaisty P. (2012) Business Representation in the State Duma. Waiting for Reform under Putin and Medvedev (eds. Jonson L., White S.), Palgrave Macmillan, pp. 140-158.

Culpepper P. (2015) Structural Power and Political Science in the Post-crisis Era. Business and Politics, vol. 17, no 3, pp. 391-409.

Davydova A. (2015) RSPP dobilsya peremeny v klimate [RSPP Has Changed the Climate]. Kommersant.ru, December 22, 2015. Available at: https://www.kommersant.ru/doc/2882957, accessed 27.09.2018.

Duvanova D. (2011) Firm Lobbying Versus Sectoral Organization: The Analysis of Businessstate Relations in Post-communist Russia. Post-Soviet Affairs, vol. 27, no 4, pp. 387-409.

Gajdar E., Telen' L. (2009) Svoyu povinnost' otbyl [I Have Done My Duty]. Moskovskie novosti, December 16, 2009. Available at: https://www.svoboda.org/a/1905525.html, accessed 27.09.2018.

Gans-Morse J. (2012) Threats to Property Rights in Russia: From Private Coercion to State Aggression. Post-Soviet Affairs, vol. 28, no 3, pp. 263-295.

Gel'man V. (2015) Modernizatsiya, instituty $i$ "porochnyj krug» postsovetskogo neopatrimonializma [Modernization, Institutions and the 'Vicious Circle' of Post-Soviet Neopatrimonialism], Saint Petersburg: Evropejskij universitet v Sankt-Peterburge.

Golosov G. (2008) Elektoral'nyj avtoritarizm v Rossii [Electoral Authoritarianism in Russia]. Pro et Contra, vol. 12, no 1, pp. 22-35.

Hale H. (2005) Why not Parties in Russia?: Democracy, Federalism, and the State, Cambridge University Press.

Hale H. (2010) Eurasian Polities as Hybrid Regimes: The Case of Putin's Russia. Journal of Eurasian Studies, vol. 1, no 1, pp. 33-41.

Jessop B. (1978) Capitalism and Democracy: the Best Possible Political Shell. Power and the State (eds. Littlejohn G., Smart P., Wakeford J., Yuval Davis N.), London: Croom Helm, pp. 10-51.

King L. (2002) Postcommunist Divergence: a Comparative Analysis of the Transition to Capitalism in Poland and Russia. Studies in Comparative International Development, vol. 37, no 3, pp. 3-34.

Koroli goszakaza-2016: rejting Forbes [Kings of State Contracts-2016: Forbes Rating] (2016). Forbes, February 25, 2016. Available at: http://www.forbes.ru/rating-photogallery/313039koroli-goszakaza-2016-reiting-forbes, accessed 27.09.2018.

Krichevskij N., Inozemtsev V. (2009) Ekonomikoj pravyat oligarkhi [The Economy Is Ruled by the Oligarchs]. Vedomosti, August 17, 2009. Available at: https://www.vedomosti.ru/ opinion/articles/2009/08/17/jekonomikoj-pravyat-oligarhi, accessed 27.09.2018.

Lamberova N., Sonin K. (2018) The Role of Business in Shaping Economic Policy. The New Autocracy: Information, Politics, and Policy in Putin's Russia (ed. Treisman D.), Washington, D.C.: Brookings Institution Press. 
Lebedev V., Sivakov D. (2011) Investitsii na ruchnom upravlenii [Investment Under Manual Control]. Ekspert.ru, April 11, 2011. Available at: http://expert.ru/expert/2011/14/nvestitsiina-ruchnom-upravlenii/, accessed 27.09.2018.

Ledyaeva S., Karhunen P., Kosonen R., Whalley J. (2015) Offshore Foreign Direct Investment, Capital Round-tripping, and Corruption: Empirical Analysis of Russian Regions. Economic Geography, vol. 3, no 91, pp 305-341.

Lindblom C. (1982) The Market as Prison. The Journal of Politics, vol. 44, no 2, pp. 324-336.

Luong P., Weinthal E. (2004) Contra Coercion: Russian Tax Reform, Exogenous Shocks, and Negotiated Institutional Change. American Political Science Review, vol. 98, no 1, pp. 139-152.

Markus S. (2007) Capitalists of All Russia, Unite! Business Mobilization under Debilitated Dirigisme. Polity, vol. 39, pp. 277-304.

Martus E. (2017) Contested Policymaking in Russia: Industry, Environment, and the "Best Available Technology" Debate. Post-Soviet Affairs, vol. 33, no 4, pp. 276-297.

Marx K., Engels F. (1955) Sochineniya [The Collection of Works], Moscow: Gosudarstvennoe izdatel'stvo politicheskoj literatury.

Matveev I. (2017) Konets «stabil'nosti»: politicheskaya ekonomiya peresekayushchikhsya krizisov v Rossii s 2009 goda ['Stability's End: the Political Economy of Russia's Intersecting Crises since 2009]. Sotsiologicheskoe obozrenie, vol. 16, no 2, pp. 29-53.

McFaul M. (1995) State Power, Institutional Change, and the Politics of Privatization in Russia. World Politics, vol. 47, no 2, pp. 210-243.

Miliband R. (1969) The State in Capitalist Society, New York: Basic Books.

Miliband R. (1973) Poulantzas and the Capitalist State. New Left Review, no 82, pp. 83-92.

Mokrousova I., Todorova M. (2016) Poleznye resursy [Useful Resources]. Forbes, May 3, 2016. Available at: http://www.forbes.ru/forbes/issue/2016-05/317605-poleznye-resursy, accessed 27.09.2018.

Müller M. (2011) State Dirigisme in Megaprojects: Governing the 2014 Winter Olympics in Sochi. Environment and Planning A, vol. 43, no 9, pp. 2091-2108.

Orttung R. (2004) Business and Politics in the Russian Regions. Problems of Post-Communism, vol. 51, no 2, pp. 48-60.

Pappe Y. (2000) «Oligarkhi». Ekonomicheskaya khronika 1992-2000 [The “Oligarchs". The Economic Chronicles of 1992-2000], Moscow: HSE.

Pappe Y., Galuhina Y. (2009) Rossijskij krupnyj biznes: pervye 15 let ekonomicheskie khroniki, 1993-2008 [Russian Large Business: the First 15 Years of the Economic Chronicles, 1993-2008], Moscow: HSE.

Pavlovskij G. (2003) O negativnykh posledstviyakh «letnego nastupleniya» oppozitsionnogo kursu prezidenta RF men'shinstva [On the Negative Consequences of the "Summer Offensive" of the Minority in Opposition to the President's Course]. Novaya gazeta, September, 2003. Available at: http://2003.novayagazeta.ru/nomer/2003/67n/n67n-s00. shtml, accessed 27.09.2018.

Pervaya ochered' Boguchanskoj GES zapushchena v tekhnicheskuyu ekspluatatsiyu [The First Part of the Boguchanskaya Hydroelectric Plant Is Now Operative] (2012). Kremlin.ru, October 15, 2012. Available at: http://kremlin.ru/events/president/news/16643, accessed 27.09.2018.

Petrov N., Lipman M., Hale H. (2014) Three Dilemmas of Hybrid Regime Governance: Russia from Putin to Putin. Post-Soviet Affairs, vol. 30, no 1, pp. 1-26.

Pirani S. (2010) Change in Putin's Russia: Power, Money and People, Pluto Press.

Ponomarev V. (2012) Poslednij dolgostroj [The Last Neverending Project]. Ekspert.Online.ru. Available at: http://expert.ru/siberia/2012/42/poslednij-dolgostroj 2/, accessed 27.09.2018.

Pryamaya liniya s Vladimirom Putinym [The Direct Line with Vladimir Putin] (2014). Kremlin.ru, April 17, 2014. Available at: http://kremlin.ru/events/president/news/20796, accessed 27.09.2018.

Rutland P. (2008) Putin's Economic Record: Is the Oil Boom Sustainable? Europe-Asia Studies, vol. 60, no 6, pp. 1051-1072.

Shinar C. (2015) The Russian Oligarchs, from Yeltsin to Putin. European Review, vol. 23, no 4, pp. 583-596. 
Simakov D. (2008) Za 2006 g. Deripaska poluchil ot «Rusala» \$4,6 mlrd dividendov, soobshchila «Renova» Veksel'berga [Vekselberg's "Renova" Reports Deripaska's "Rusal" Paid \$4,6 bln in Dividends in 2006]. Kompromat.ru, January 15, 2008. Available at: http://www.compromat.ru/page 22042.htm, accessed 27.09.2018.

Stanovaya T. (2017) Politika dogonyaet. O chem ne skazal Mikhail Fridman [Politics Catches Up. The Things Mikhail Fridman Left Unsaid]. Republic.ru, January 10, 2017. Available at: https://republic.ru/posts/88831, accessed 27.09.2018.

Stavrakis P. (1993) State Building in post-Soviet Russia: The Chicago Boys and the Decline of Administrative Capacity, Kennan Institute for Advanced Russian Studies, The Wilson Center.

Struchenevskij A. (2016) Krupnyj biznes nanosit otvetnyj udar [Big Business Strikes Back]. Strategicheskie resheniya i risk-menedzhment, no 6, pp. 48-53.

Sukhanov V. (2010) Ya by zapretila publichnye popytki otmenit' l'gotu po nalogu na pribyl' [I Would Prohibit Public Attempts to Remove the Income Tax Break]. Kommersant.ru, September23,2010.Availableat: https://www.kommersant.ru/doc/1508519, accessed 27.09.2018.

Swank D. (1998) Funding the Welfare State: Globalization and the Taxation of Business in Advanced Market Economies. Political Studies, vol. 46, no 4, pp. 671-692.

Thompson W. (2005) Putin and the "Oligarchs": A Two-Sided Commitment Problem. Leading Russia: Putin in Perspective: Essays in Honour of Archie Brown (ed. Pravda A.), Oxford: Oxford University Press, pp. 179-202.

Treisman D. (2016) Russia's Billionaires. American Economic Review, vol. 106, no 5, pp. 236-241.

Turovskij R. (2005) Vlast' i biznes v regionakh Rossii: sovremennye protsessy obnovleniya regional'noj elity [State and Business in the Russian Regions: Current Processes of Regional Elite Turnover]. Regional'naya elita v sovremennoj Rossii [Regional Elite in Modern Russia] (ed. Frukhtmann Ya.), Moscow: Fond «Liberal'naya missiya», pp. 160-169.

Visser O., Mamonova N., Spoor M. (2012) Oligarchs, Megafarms and Land Reserves: Understanding Land Grabbing in Russia. The Journal of Peasant Studies, vol. 39, no 3-4, pp. 899-931.

Volkov V. (2012) Silovoe predprinimatel'stvo, XXI vek: ekonomiko-sotsiologicheskij analiz [Violent Entrepreneurship, $21^{\text {st }}$ Century: Economic and Sociological Analysis], Saint Petersburg: Evropejskij universitet v Sankt-Peterburge.

Winters J. (1996) Power in Motion: Capital Mobility and the Indonesian State, New York: Cornell University Press.

Yakovlev A. (2006) The Evolution of Business: State Interaction in Russia: From State Capture to Business Capture? Europe-Asia Studies, vol. 58, no 7, pp. 1033-1056.

Yakovlev A. (2015) Smysl i naznachenie voinstvennosti'[The Meaning and the Goal of Martialism]. Rossiya v global'noj politike, vol. 13, no 6, pp. 119-134.

Zudin A. (2013) Gosudarstvo i biznes v Rossii (Opyt primeneniya kontseptsii Norta-UollisaVajngasta). Stat'ya 2. Tendentsii razvitiya otnoshenij mezhdu gosudarstvom i biznesom [The State and Business in Russia According to North-Wallis-Weingast Theory. Article 2. Tendencies in State-Business Interaction]. Obshchestvennye nauki i sovremennost', no 3, pp. 5-17. 